\title{
Lean Production Role in Improving Public Service Performance in Egypt: Challenges and Opportunities
}

\author{
Dr. Wael Omran Aly \\ PhD. of Public Administration \\ High institute of computer sciences and information systems \\ New Cairo Academy- Egypt \\ Email:wael.omran@ymail.com
}

Accepted: April 13, 2014

Doi:10.5296/ jpag.v4i2.5415 URL: http://dx.doi.org/10.5296/ jpag.v4i2.5415

\begin{abstract}
For decades, Egypt strives to adopt development administration principles and techniques; in order to transform their conventional traditional public service into modern developing new one; able to meet people expectations. While Current conventional public service in Egypt deals with regulatory aspects of administration such as law and order, judicial administration and revenue collection; new public service is concerned with the socio-economic developmental activities relevant to new public management principles.

Thus, traditional public service is structure-oriented while new public service is actionoriented. Many third world countries failed in realizing such desired shift by converting its conventional public service to effective new public service; able to satisfy people needs by implementing plans, policies, programs and projects necessary for sustainable development purposes. Such bad governance would lead the frustrated people to go up against such government; as it happens lately in Egypt.

Hence, in this paper we aim to shed light on lean production techniques; as a suggested philosophy that can be adopted by the crippled government of Egypt; to convert its traditional ineffective public service performance into effective new one; able to fulfill the desired developmental programs and projects that meet people needs and aspirations.
\end{abstract}

Keywords: Conventional public service, new public service, new public management, lean production. 


\section{Overview}

Governments around the world - whether they are in developing or developed countriesstrive to deliver to their citizens better education, healthcare, transportation services and so forth. They know definitely that people are impatient; they expect to see quick change and development on the ground. But the scarcity and limitation of required financial and economical resources necessary to meet such public expectations; hinder the government's efforts in such arena.

Consequently, the government in Egypt is often obliged by the resources limitation; to cut public programs in a way that may weaken the quality of the public service performance and increase people dissatisfaction. Therefore, the need to get value for money from the Egyptian government at all levels becomes critical especially after the recent people uprisings.

To address such problems the Egyptian government - as we suggest hereby- had to adopt lean techniques long used in private sector, in order to improve its conventional operating system for public service delivery and transform it to the better. The government through such techniques could realize the paradox of cutting the cost of public service and increasing the quality of its performance.

Hence, in such paper we will shed light firstly on lean production basics and aspects and its relevance to recent new public management trends. Secondly, we will discuss and analyze the problems and challenges that may face lean production application in the Egyptian public service. Finally, a suggested model for the one stop shop (OSS) as a lean production application to the Egyptian public service will be adapted.

\section{2- Lean production philosophy: basics and aspects}

In such section, we will discuss lean production basics to show its relevance to new public service principles'. In addition, we will encapsulate the main principles and techniques of lean production thinking.

\subsection{Lean production basics and public service realm}

Originally, lean was developed as a production philosophy and quality system resemble to Total quality management (TQM) and Six Sigma methodologies, with elements of both craft production and mass production. Lean thinking, with its emphasis on standardization, tries to eliminate inventory and improve processes. So, Time between a customer requesting a service and then receiving it is minimized (Edward D. Arnheiter \& John Maleyeff, 2005).

Consequently, the concept of lean production, trying to combine efficiency with a customer-oriented approach. Various tools that together came to be known as lean production were first pioneered at the Toyota Corporation and were later used in the automotive, manufacturing and service industry and eventually health care (see appendix 1).

The assumptions of value of this production philosophy, usually considered as an alternative to mass production, are the attempt of minimizing the use of resources, a customer-driven 
interpretation of the concept of value, the re-engineering of processes in the effort of eliminating those without real added-value, a customer-needs oriented process, therefore transforming the classical accumulative production into a "just in time" process without any need for stocks (Womack, Jones \& Roos, 1990).

Thus, The key concept in lean production thinking is 'value'. Value is defined as the capability to deliver exactly the (customized) product or service a customer wants with minimal time between the moment the customer asks for that product or service and the actual delivery at an appropriate price (Hines P, Holweg \& others, 2004). By defining 'what customers want', process-steps can be divided in value-adding and non-value adding. Value adding activities contribute directly to creating a product or service a customer wants. Non-value adding activities do not and are called waste. Of course, waste needs to be removed or avoided (Womack. J \& Jones. D, 2003).

So, lean production can be defined aggregately as: "An operational system that maximizes value added, reduces essential support and eliminates waste in all processes throughout the value stream" ( Rooney. S \& Rooney. J, 2005).

As per the case in public service realm, the well-known evolution of the role of the State (direct producer, the dramatic reforms of the New Public Management, until the governance approach in its diverse interpretations), have naturally been translated in a series of new theories, techniques and tools, often coming from the corporate world, that public administrations have implemented into the public service organizations with different fortune (Hines, p. Martins \& others, 2008) .

We also need to take into considerations the principles of new public service that Janet and Robert Denhardt proposed to guide public administrators in increasing their performance. Whereby the primary role of public administrators is to help citizens articulate and meet their mutual interests; and also public servants must be attentive to more than the market; they must also attend to statutory and constitutional law, community values, political norms, professional standards, and citizen interests. Finally, Public organizations and the networks in which they participate are more likely to be successful in the long run if they are operated through processes of collaboration based on a respect for people needs and expectations (Denhardt .j \& Denhardt. R, 2003).

Hence, recently the Lean Production Theory and more specifically processes re-engineering, has been debated and applied in the field of public services in consistency with the previous principles (Elkhuizen. S \& others, 2006). In this context, some steps in the development and the experimentation are particularly critical for two main reasons: the intangible features of the service and the fact that production and consumption happen simultaneously. As a matter of fact, the moment of service delivery becomes the moment of truth; the moment when customers come into contact with the company services, they make a judgment about their quality (Mc Nary, L.D , 2008). Therefore recruiting highly qualified personnel and making a preliminary evaluation of their motivations, attitudes and competencies becomes an essential element (De Treville S. \& others, 2006). 
It is not by chance that the academic debate about lean production application in public service is intense and diverse. some adopting it openly, others acknowledging it by highlighting potential weak points such as the complexity to reconcile managerial times and pace with the bureaucratic ones, the organizational culture that is needed to advocate those innovations and the possibility of favoring increases in the service demand with unavoidable consequences in the level of the taxation (Peter Hines, 2009).

However, the main question that seems to emerge is: how the Lean Production is applicable in the Public Sector?. In this paper we try to make a contribution to this research field, reflecting on the Egyptian case.

\subsection{Lean production Aspects and Principles}

In order to make lean production applicable within public services organizations; we must take into consideration the different organizational aspect for the lean production. They are as follows (Nelson Peterson \& others, 2007):

\subsubsection{Operational aspects of lean production}

On an operational level, standard organizing tools like value stream mapping are available to create value. Application of these instruments seems reasonably straightforward and they are discussed in most papers of lean thinking. Using them, have reduced waste in inventory, reduced waiting times (WTs) and improved productivity (Jones, D. \& Mitchell, A., 2006). In order to put such lean production techniques into operation; the following principles must be adopted (McQuad, D., 2008):

Identify Customers and Specify Value - The starting point is to recognise that only a small fraction of the total time and effort in any organisation actually adds value for the end customer. By clearly defining Value for a specific product or service from the end customer's perspective, all the non value activities - or waste - can be targeted for removal.

Identify and Map the Value Stream - The Value Stream is the entire set of activities across all parts of the organisation involved in jointly delivering the product or service. This represents the end-to-end process that delivers the value to the customer. Once you understand what your customer wants the next step is to identify how you are delivering (or not) that to them.

Create Flow by Eliminating Waste - Typically when you first map the Value Stream you will find that only $5 \%$ of activities add value, this can rise to $45 \%$ in a service environment. Eliminating this waste ensures that your product or service "flows" to the customer without any interruption, detour or waiting.

Respond to Customer Pull - This is about understanding the customer demand on your service and then creating your process to respond to this. Such that you produce only what the customer wants when the customer wants it.

Pursue Perfection - Creating flow and pull starts with radically reorganising individual process steps, but the gains become truly significant as all the steps link together. As this 
happens more and more layers of waste become visible and the process continues towards the theoretical end point of perfection, where every asset and every action adds value for the end customer.

In following these five principles of Lean you will implement a philosophy that will become "just the way things are done". You are ensuring that you are driving towards the overall organisational strategy by constant review of your processes to ensure that they are constantly and consistently delivering value to your customer. This allows the organization to maintain its high level of service whilst being able to grow and flex with a changing environment and it does this through implementing sustainable change (John Lucey, 2005).

\subsubsection{Socio-technical aspects of lean production}

Lean interventions have the potential to make jobs more simple and repetitive or turn them into jobs that require more thinking, planning and responsibility. These changes affect those who execute these processes (making jobs too simple or repetitive, for example, may lead to resistance and anxiety). Sociotechnical systems theory studies these interaction between social (human behavioral) and technical elements (technologies) to create an advocate organizational culture for lean production (Tom Joosten \& Others, 2009).

The emphasis on lean as operational, process-oriented concept has directed attention away from these sociotechnical aspects. Much of criticisms has centered on the question how a technical system that explicitly promotes standardized repetitive work can still be attractive and motivating to workers. A common opinion is that even though lean organizations have some practices that seek to promote worker well-being (e.g. extensive training, internal promotion and pay for performance), 'respect' for humans is only a pleasant by-product next to higher productivity and quality (Womack, J.P., 1996).

Hence, we assure the importance of both operational and sociotechnical aspects of lean production. Some lean advocates even propose that carefully balancing operational and sociotechnical aspects can produce improvements that cannot be achieved by operational or sociotechnical interventions alone. They argue that this synergy accounts for the superior performance of lean organizations (Emiliani, M.1., 2003). The term 'cumulative capabilities' is used when high performances are achieved in multiple areas, like quality, speed and flexibility on the one hand and working conditions and organizational climate on the other hand (Flynn, B. \& Flynn, A., 2004) (see fig. 1).

So, a cumulative capability for lean production occurs when the introduction of a care pathway leads to shorter admission times (operational aspects), while maintaining a positive organizational climate (sociotechnical aspect) and achieving better outcomes, rather than trading off a shorter admission time at the expense of workers' satisfaction (Peter Hines \& others, 2004). 


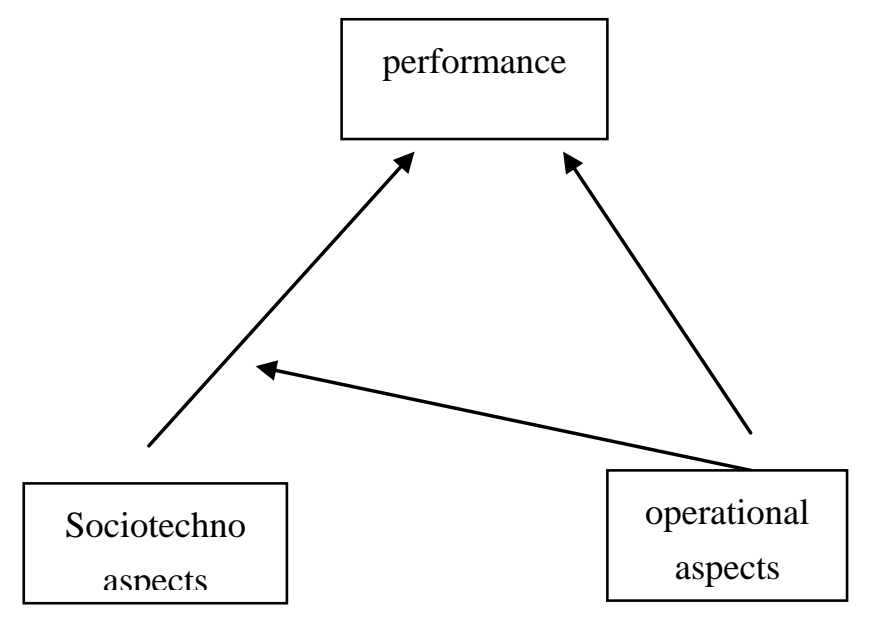

Fig (1): cumulative capabilities for lean production

\section{Lean production application in Egyptian public service: challenges and opportunities}

Historically, the bureaucracy served as an indispensable arm of the Egyptian regime. It ensured stability and order, produced and distributed public goods, punished the enemies of the regime and maintained its grip on power through rigging elections. Consequently, people uprisings' escalated reflecting their dissatisfaction; and to declare the failure of public service in responding to their needs. Therefore, the Egyptian government priority nowadays is to find ways for responding quickly to citizens needs; regarding the quality and time of service delivery (Omran, W, 2013).

It is important to mention hereby, that there were some attempts for lean production application- by applying the one stop shop (OSS) for municipal and investors services- in the Egyptian public sector in the last decade. But unfortunately, they failed due to the absence of political commitment and administrative efficacy.

Hence, the government had to resurrect such one stop shop (OSS) project in the public service- as a manifestation of lean production thinking- without any delay to ensure people satisfaction and maintain social stability in the society on such critical time.

\subsection{One stop shop for citizens (OSS)}

The idea of the OSS comes from a different approach: whilst including the information about and the access to administrative files in a functional organization vision of public administration, at the same time the OSS promotes a new philosophy of service (or of results) that start by redesigning backwards ambiguous processes, optimizing times, and with responsibilities that are clearly defined. Furthermore times and expected results are reasonably foreseeable and citizens are suitable informed about them. In this way public administration changes not only the approach to service but also the way of responding to all 
stakeholders demands (Francesco Poddighe \& others 2009).

With the creation of the OSS, finally, the relationship between citizens and public administration takes place through a single front office/one window having as its main aim ( Miniami Gebre \& Others, 2012):

1) To overcome the administrative fragmentation of bureaucratic procedures;

2) To increase the productivity and, consequently, management's efficiency;

3) To develop a new capacity of active listening;

4) To establish a two-way channel of communication, thus enhancing transparency and accountability;

5) To open new possibilities of social and informal control by citizens over public administration's services.

In operational terms, the basic assumption (in line with Lean Thinking principles) has been that complexity, if not managed, is a cost in itself. The immediate consequence has been the necessity to reconsider the whole process of production (or better the administrative one, in this case), involving all the organizational bureaucratic functions. The focus has not been on the reduction of surplus stock or project design errors but on the diminution of downtime, on the flexible use of spaces and equipment, on the increase of opening hours and on the rationalization of supplies (Nina Bahatia \& John Drew, 2006).

The focal point of the re-engineering has been the customer (citizen, entrepreneur, professional) and, more specifically, the moment of the actual contact between the customer and the public administration. Every "final" service -that is a service directed to an external actor- was analyzed to single out every process included. Then, each process has been divided into its different phases (O'toole, L.J, 1997). Out of these, only the so-called front-office functions or "contact" phases have been assigned to the OSS, while those related to back-office (preliminary and decision-making phases) have remained within the responsibility of single units (McNary, L.D, 2008).

Such reorientation helps to transform work processes and agency structures to those driven by meaningful outcomes; a shift from segmentation to integration, from division labor to seamless work. Re-engineering involves enhancing those activities that may be considered value-added-activities that give customers/citizens more of what they are willing to pay for and cutting functions that merely stand in the way (Pollitt, C., 1993).

Thus, the key to successful re-engineering is to separate the core processes from the other task, enabling the critical activities to be carried out more effectively (Ongaro, E. , 2009).

At the end, the governmental unit published an operational handbook that lists the processes of each service offered to the users, and highlights the "moments of contact" between the public administration and the external actor (particularly the first contact defined as "input" and the last one defined as "output") (Radnor, Z \& Walley, P., 2008). 


\section{Macrothink}

Moreover the handbook identifies the different phases of the process and assigns the respective responsibilities to the OSS or to other units (see fig. 3).

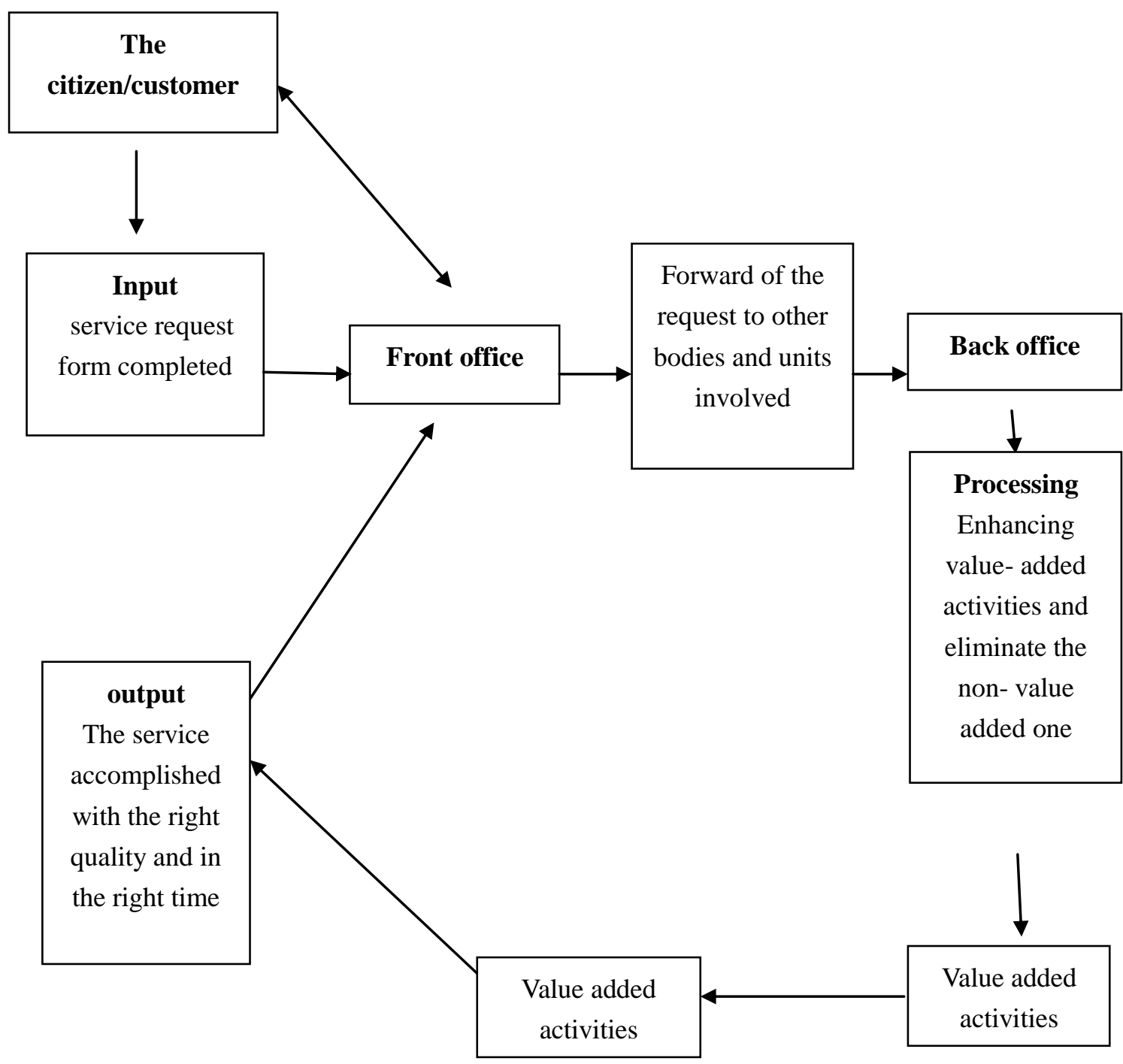

Fig (2): OSS operational model

\section{2 challenges for the one stop shop application:}

Many barriers/challenges may impede the government attempts' in Egypt to realize such proposed model for lean production "the one stop shop"; they are as follows (Hussein Mahmoud, 2011) (Omran, A., 2013) (Scorsone, E., 2008): 


\section{Political challenges:}

Egypt suffered- especially during the last three years after January revolution- from lack of political stability; whereby three presidents and around seven cabinets had been changed. Such quick political changes surely hamper any reforming attempts. Therefore; the bureaucracy performance deteriorated; and people dissatisfaction escalated. Thus, lean production application requires a political commitment and pervasive vision from the political leadership of the country.

\section{Administrative Challenges:}

For decades, the authoritarian political regime in Egypt had deliberately created a highly centralized public bureaucracy; where citizens faced time-consuming processes in public organizations due to the top-down bureaucratic system. Such deplorable bureaucracy maintains its rigidity via mechanistic centralized structure, complicated rules and long detailed procedures. Whereby such rigid bureaucracy is operated by mediocre dissatisfied public employees; suffered from lack of efficient training and effective incentives structure, resisting any reforming attempts- such as lean production application- to protect their power and corrupted self interests.

Consequently, people were whining for a long time about the decay of public service quality; which came to symbolize the decay of the regime itself and its disconnect with the people needs.

\section{Economical challenges:}

The application of lean production requires the availability of funds to realize such reforming. Whereby the government must bear the cost of public activities reengineering to design end to end processes; relying on value added activities that cope with citizen needs. And also the cost for employees trainings, reinforcements and compensations.

Unfortunately, Egypt faces lately an economical crisis; especially after the recent consecutive revolutionary trends and the political instability which had negative impacts on the growth of the domestic income. The matter that hinder its chances in applying such reform.

\section{Legal challenges:}

In Egypt, the lack of transparency in rules, laws, and processes creates a fertile ground for corruption. Rules are often confusing, the documents specifying them are not publicly available, and at times, the rules are changed without properly publicized announcements. Laws or regulations are written in a way that only trained lawyers can understand and are often conceptually and not just linguistically opaque about important aspects thus leaving grounds for different interpretations. Sometimes also such laws and rules contradict together.

Hence, the application of lean production is too difficult in the shadow of such complicated, confusing and contradicted legal environment that govern the public service sector in Egypt. 


\section{Social and Cultural challenges:}

The lack of people confidence in the government intensions' is a fact here in Egypt. The rampant corruption that encompasses the public service apparatus for years is a big reason for that. Also the bad reputation that the public service had among the people in the society; as its employees are mediocre, don't respect the citizens, corrupted, must get money in return of any service to ensure its quality....

Meanwhile, the application of lean management require trustee collaborated relationship between citizens (customers) and the public service organizations; to identify the needs and wants of such customers. In Egypt, such relationship has not existed yet; which hamper the lean production efforts in public service.

\subsection{Requirements and Opportunities for effective OSS application}

From the previous analysis we can aggregate the main requirements to overcome the previous challenges for effective OSS application - as a lean production manifestation- in Egypt. Such requirements had to be procured by the Egyptian government shortly; as they represent the only opportunity to pave the way for an effective lean production application of OSS.

Thus, the government to do so; it had to adopt the following suggested good governance policies' :

- Conveying the public thrust- due the political jargon sprang in Egypt after 2011 and 30 June 2013 uprisings- to different governmental units, and to cooperate with the legislative authority to issue laws that enhance decentralization, people participation and corruption elimination. Then, a trustee relationship will take place between people and the public service organizations'.

- Energizing the issuing of legislations and laws necessary to simplify the rules and procedures.

- filtrating the existing administrative procedures, Rules and regulations to avoid any potential contradictions Or duplications (Yassin, E., 1994).

- Providing necessary manuals for various managerial procedures, its costs and time of delivery.

- Enhancing the completion of current e.government applications to facilitate citizens' procurement for various services, and to energize data and information flow among different users.

- Creating an effective system to citizens' relation management (CRM); to receive their complaints and resolve them.

- Encouraging mass media organizations, NGOs and grass organization to play critical role in mobilizing the public opinion around the importance of such project; by informing people up to date about its roles and its developmental progress.

- Catalyzing the implementation of civil services reforming programs. Such programs must 
rely on new public management principles (NPM); such as (Hood, C.C., 1991):

1) restructuring the conventional huge rigid apparatus into small size flexible effective one; free of any duplication or overlapping; 2) reengineering the current administrative process to facilitate service procurement procedures and to enhance value- added activities. So, the quality is ensured; 3) adoption of human resources management systems to surrogate conventional personal management programs; 4) adjustment of staffing systems and training sessions to enhance job effectiveness as well as employees' satisfaction. So, the right person will fill into the right post; 5) redesign the wages systems and employees fringe benefits (healthcare insurance, social incentives...) to realize employees' financial satisfaction;

6) imposing an effective code of ethics to govern employees' behavior is a must; consistent with reinforcement procedures to ensure its application; 7) assuring the propagation of governmental information, rules and procedures; whereby, the majority of government agencies still use conventional red tapes and ask for unneeded document.

- Adopting of management by results as an adequate controlling method (outcomes centered) instead of traditional stages of executive control (process centered).

- Rationalizing the costs of different governmental units by eliminating the unnecessary expenses; whereas such cutting could be directed to finance OSS program.

- Mobilizing the necessary resources for the application of lean production program OSS; whether such resources are financial or physical. It can procure such various resources by local funding or by foreign international grants and donations programs.

\section{Conclusion:}

In this paper, we discussed lean production thinking as a management approach that focuses on operational aspects and the sociotechnical dynamics. Whereby lean production can considered as an operational system that maximizes value added, reduces essential support and eliminates waste in all processes throughout the value stream".

Hence, by reengineering the public activities -taking into consideration the needs of the internal customer (the employee) and the external customer (the citizen)- we can formulize the convenient value stream to deliver the public service in the right quality and the right time.

Consequently, we illustrated how these insights can be applied to public service. Whereby we suggest to apply the one stop shop (OSS) based on Lean Thinking approach into the Egyptian public service; which frames a policy aimed at saving as an opportunity for service innovation. The occurrence enhanced the quality of public service performance (which is an essential priority for services users) and, then, made easier to adopt a performance appraisal system and a performance pay system.

Accordingly, we analyzed the problems and challenges that may face lean production application in the Egyptian public service. Such challenges may arise from the legal, political, social, economical, administrative and cultural context.

Finally, we propose some policies that the Egyptian government had to follow ensure the 


\section{Macrothink Institute $^{\text {TM }}$}

effective application of suggested lean production program (the one stop shop) to public service. such policy must rely on good governance indices'; as the necessity of the political commitment, the collaboration between all the societal stakeholders and the government, the adoption of new public management principles, the transparency, the accountability and the economical and financial efficacy is a must.

\section{References:}

- De Treville S, Antonakis J. Could lean production job design be intrinsically motivating? Contextual, configurationally and levels-of-analysis issues, Journal of Operation Management, 2006, vol.24, pp. 99-123.

- Denhardt, Janet V. and Robert B. Denhardt The New Public Serving, Not Steering, Armonk, NY: M.E. Sharp, 2003, pp. 88-90.

- Edward D. Arnheiter and John Maleyeff, The integration of lean management and Six Sigma, The TQM Magazine, Emerald Group Publishing Limited, 2005, Vol. 17 No. 1, pp. $5-18$

- Elkhuizen S, Limburg M, Bakker P et al. Evidence-based re-engineering: re-engineering the evidence, International Journal for Health Care Quality Assurance, 2006; vol. 19, pp.477-499.

- Emiliani, M.L., Better Thinking, Better Results, The Center for Lean Business

- Flynn B, Flynn E. An exploratory study of the nature of cumulative capabilities. Journal of Operation Management, 2004; vol.22, pp. 439-57.

- Francesco Poddighe ,Alessandro Lombrano \& Mario Iannielo, Lean Production and One-Stop Shop For Municipal Services, Public Administration \& Management, 2009, Vol. 16, No. 1, pp. 1-20

- Hines P, Holweg M, Rich N. Learning to evolve: a review of contemporary lean thinking. International Journal for Operational Production Management, 2004; vol. 24, pp. 994-1011.

- Hines, P., Martins, A.L. \& Beale J.. Testing the Boundaries of Lean Thinking: Observations from the Legal Public Sector. Public Money \& Management, 2008, vol. 28 , no. 1 , pp. $35-40$.

- Hood, C.CA Public Management for All Seasons?, Public Administration, 1991, vol. 69 no. 1, pp. 3-19.

- Hussein Mahmoud Hassan, An analytical study for corruption causes in Egypt before 25th January revolution: towards future vision to preclude this phenomenon, Social Contract Center, 2011, p.12.

- issues and observations, International Journal for Quality in Health Care, 2009, vol. 21, no. 5 , pp. $341-347$ 


\section{Macrothink}

Journal of Public Administration and Governance ISSN 2161-7104 2014, Vol. 4, No. 2

- John Lucey, Nicola Bateman \& Peter Hines, Why major lean Transformations have not been sustained, Management services: Journal of the institute of management services, 2005, vol. 49, no.2, pp. 9-13.

- Jones D, Mitchell A. Lean Thinking for the NHS. London: NHS Confederation, 2006.

- Liker J. The Toyota Way - 14 Management Principles from the World's Greatest Manufacturer. New York, NY: McGraw-Hill, 2004, p.11.

- Management, Kensington, CT, 2003, PP.2-11.

- McNary, L.D. Quality Management in the Public Sector: Applying Lean Concepts to Customer Service in a Consolidated Government Office. Public Administration Quarterly, 2008, vol.32, no 2, 282-304.

- McQuade, D. New Development: Leading Lean Action to Transform Housing Services. Public Money \& Management, 2008, vol.28, no. 1, pp. 57-60.

- Miniam Gebre, Petter Hallman, Mark Minukas and Becca O,brien, Transforming government performance through lean management, McKinsey center for government, December 2012, pp.3-16.

- Nelson Peterson D, Leppa C. Creating an environment for caring using lean principles of the Virginia mason production system. Journal of Nursery Administration, 2007; vol.37 pp.287-94.

- Nina Bahatia \& John Drew, Applying lean production to public sector, Mckinsey Quarterly, June 2006, pp. 1-7.

- O'Toole, L.J. Treating Networks Seriously: Practical and Research-Based Agendas in Public Administration, Public Administration Review, 1997, vol. 57, no. 1, pp. 45-52.

- Omran, W. ,A., Bad Governance and Failure of Development Progress in Egypt: Causes, Consequences and Remedies, journal of public administration and governance, vol 3 , no. 4, 2013, pp. 42-45.

- Ongaro, E.. Public Management Reform and Modernization. Cheltenham: Edward Elgar, 2009, pp. 54-57.

- Peter Hines, Matthias holweg \& nick Rich, Learning to evolve: A review of contemporary lean thinking, international journal of operations and production management, 2004, vol. 24, no.10, pp.994-1101.

- Peter Hines, must do better: Applying lean in the public sector, public sector executive, Sep/Oct 2009, pp. 34-39,

- Pollitt, C. Managerialism and the Public Services: the Anglo-American Experience (2nd Edn.). Oxford: Blackwell,1993, pp. 76-81.

- Radnor, Z. \& Walley, P. Learning to Walk Before We Try to Run: Adapting Lean for the Public Sector. Public Money \& Management, 2008,vol. 28, no.1, pp. 13-20. 
- Rooney S, Rooney J. Lean glossary, Quality Progress, 2005, vol. 38, pp. 41-47.

- Scorsone, E.A. New Development: What are the Challenges in Transferring Lean Thinking to Government?. Public Money \& Management, 2008, Vol. 28, no. 1, pp. 61-64.

- Tom Joosten, Inge Bongersi \& Richard Janssen, Application of lean thinking to health care:

- Womack J, Jones D. Lean Thinking. New York, NY: Simon \& Schuster, 2003.

- Womack, J.P. and Jones, D.T. Lean Thinking, Simon \& Schuster, New York, NY, 1996, pp. 90-98.

- Womack, J.P., Jones, D.T. \& Roos, D., The Machine That Changed the World. New York: Rawson/Macmillan ,1990, pp. 34- 41.

- Yassin, E. (ed.), Egyptian Bureaucracy, an Empirical Study, Cairo: Al Ahram Center for Political and Strategic Studies, 1994, pp. 35 -39. 
Appendix 1

\begin{tabular}{|c|c|c|c|c|}
\hline $\begin{array}{l}\text { Periods in } \\
\text { the } \\
\text { development } \\
\text { of lean } \\
\text { thinking }\end{array}$ & 1980-1990 & 1990-mid-1990 & Mid-1990-1999 & 2000 till now \\
\hline $\begin{array}{l}\text { Focus on } \\
\text { approach }\end{array}$ & $\begin{array}{l}\text { Production cell and } \\
\text { line Highly } \\
\text { prescriptive, } \\
\text { using lean tools }\end{array}$ & $\begin{array}{l}\text { Shop-floor Highly } \\
\text { prescriptive, } \\
\text { imitating lean } \\
\text { organizations }\end{array}$ & $\begin{array}{l}\text { Value stream } \\
\text { Prescriptive, } \\
\text { applying } \\
\text { lean principles }\end{array}$ & $\begin{array}{l}\text { Value system } \\
\text { Integrative, } \\
\text { using } \\
\text { different } \\
\text { management } \\
\text { instruments }\end{array}$ \\
\hline $\begin{array}{l}\text { Industry } \\
\text { sector }\end{array}$ & $\begin{array}{l}\text { Automotive-vehicle } \\
\text { assembly }\end{array}$ & $\begin{array}{l}\text { Automotive-vehicle } \\
\text { and component } \\
\text { assembly }\end{array}$ & $\begin{array}{l}\text { Manufacturing } \\
\text { in } \\
\text { general-often } \\
\text { focused } \\
\text { on repetitive } \\
\text { manufacturing }\end{array}$ & $\begin{array}{l}\text { High and low } \\
\text { volume } \\
\text { manufacturing, } \\
\text { extension into } \\
\text { service } \\
\text { sectors }\end{array}$ \\
\hline $\begin{array}{l}\text { Typical } \\
\text { activity in } \\
\text { this } \\
\text { phase }\end{array}$ & $\begin{array}{l}\text { Application of } \\
\text { JIT-techniques, } 5 \mathrm{~s}, \\
\text { kanban }\end{array}$ & $\begin{array}{l}\text { Emulation of } \\
\text { successful lean } \\
\text { organizations } \\
\text { training } \\
\text { and promotion, TQM }\end{array}$ & $\begin{array}{l}\text { Improving flow; } \\
\text { process-based } \\
\text { improvements, } \\
\text { collaboration in } \\
\text { the } \\
\text { supply chain }\end{array}$ & $\begin{array}{l}\text { Improving } \\
\text { customer } \\
\text { value to } \\
\text { improve } \\
\text { organizational } \\
\text { alignment. } \\
\text { Decrease } \\
\text { variability }\end{array}$ \\
\hline
\end{tabular}


Table (1)

The evolution of lean production thinking

Source: Liker J. The Toyota Way - 14 Management Principles from the World's

Greatest Manufacturer. New York, NY: McGraw-Hill, 2004. 